\title{
Analysis of the Corrosion Scales Formed on API 5L X70 and X80 Steel Pipe in the Presence of $\mathrm{CO}_{2}$
}

\author{
A. B. Forero*, Milagros.M.G. Núñez, I. S. Bott
}

\author{
Materials Engineering Department - DEMa, Pontifical Catholic University of Rio de Janeiro - PUC-Rio, \\ Rua Marques de São Vicente, 225, Gávea, Rio de Janeiro, RJ, Brazil
}

Received: June 18, 2013; Revised: September 19, 2013

\begin{abstract}
Longitudinal welded joints samples of X70 and X80 API grade steel pipes were exposed to a deaerated $1 \% \mathrm{NaCl}$ solution containing $\mathrm{CO}_{2}$, at temperatures in the range of $25^{\circ} \mathrm{C}$ to $80^{\circ} \mathrm{C}$ for 48 hours. Analogous samples were exposed to the adjacent vapour phase. The layer of corrosion products which formed on the base metal and welded regions of the samples was investigated using mass loss determinations, scanning electron microscopy and X-ray diffraction. The corrosion products formed in tests at $60{ }^{\circ} \mathrm{C}$ and were composed of $\mathrm{FeCO}_{3}$. The $\mathrm{FeCO}_{3}$ which had initially formed at $80{ }^{\circ} \mathrm{C}$ was observed to have subsequently decomposed, resulting in a layer of $\mathrm{Fe}_{2} \mathrm{O}_{3}$
\end{abstract}

Keywords: $\mathrm{CO}_{2}$ corrosion, weight loss, SEM, X-ray diffraction, API $5 L$ X70 and X80 steels

\section{Introduction}

The selection of materials for transport of oil and gas is not always made with sufficient emphasis on corrosion resistance, but rather on good mechanical properties, ease of fabrication and low cost. Due to the material loss rates resulting from internal corrosion, it becomes necessary to thoroughly characterize the behaviour (for example: $\mathrm{CO}_{2}$ corrosion behaviour at low partial pressure, under supercritical condition) of high strength steels which are used for oil and gas pipelines such as API 5L X65, X70 and $\mathrm{X} 80^{[1-8]}$.

Well fluids and other products are transported in the oil and gas industry using pipelines. When such fluids contain an aqueous phase, they are considered to be inherently corrosive $\mathrm{e}^{1,2,5,9} . \mathrm{CO}_{2}$, also often present in such circumstances, is known for its high corrosive potential when dissolved in water. The above aspects have to be considered in order to adequately assess the integrity of the metals used in the oil and gas industry's production and transport equipment.

$\mathrm{CO}_{2}$ is a gas that reacts with water to form carbonic acid. This carbonic acid lowers the $\mathrm{pH}$ of the solution and increases the corrosion rate of steels exposed to this medium. Despite the many studies ${ }^{1-17}$ undertaken to investigate $\mathrm{CO}_{2}$ corrosion (also known as sweet corrosion), questions are still raised regarding the mechanism responsible for its occurrence. Many parameters are involved in the process and even small differences in chemical composition between one steel and another can strongly influence scale formation during $\mathrm{CO}_{2}$ corrosion $^{12}$. Among the most popular mechanisms postulated for this type of corrosion are those proposed by De Waard and Milliams ${ }^{13}$, Schmitt and Rothmann ${ }^{14}$ and George and Nešić ${ }^{15}$, all of which involve carbonic acid or bicarbonate ions formed during the dissolution of $\mathrm{CO}_{2}$ in water. Both chemical and electrochemical reactions are important factors in $\mathrm{CO}_{2}$ corrosion $^{13-15}$.

*e-mail: adriafob@esp.puc-rio.br
One of the most common chemical reactions that occur in the system is:

$$
\begin{aligned}
& \mathrm{CO}_{2(\mathrm{~g})}+\mathrm{H}_{2} \mathrm{O} \leftrightarrows \mathrm{CO}_{2} \text { (dissolved) } \\
& \mathrm{CO}_{2 \text { (dissolved })}+\mathrm{H}_{2} \mathrm{O} \rightleftarrows \mathrm{H}_{2} \mathrm{CO}_{3}
\end{aligned}
$$

Which is followed by the carbonic acid dissociation:

$\mathrm{H}_{2} \mathrm{CO}_{3} \leftrightarrows \mathrm{H}^{+}+\mathrm{HCO}_{3}$

$\mathrm{HCO}_{3} \leftrightarrows \mathrm{H}^{+}+\mathrm{CO}_{3}^{2-}$

On the surface of the stee 1 , the electrochemical reactions which occur include an anodic reaction and three cathodic reactions. The anodic reaction is:

$\mathrm{Fe} \rightarrow \mathrm{Fe}^{2+}+2 e^{-}$

And the cathodic reactions are:

$2 \mathrm{H}^{+}+2 e^{-} \rightarrow \mathrm{H}_{2}$

$2 \mathrm{H}_{2} \mathrm{CO}_{3}+2 e^{-} \rightarrow \mathrm{H}_{2}+2 \mathrm{HCO}_{3}^{-}$

$2 \mathrm{HCO}_{3}^{-}+2 e^{-} \rightarrow \mathrm{H}_{2}+2 \mathrm{CO}_{3}^{2-}$

The predominant cathodic reaction at $\mathrm{pH}<4$ is the reduction of hydrogen ions, whereas at $4<\mathrm{pH}<6$ the reduction of carbonic acid is the predominant reaction. If the $\mathrm{pH}$ is increased $(\mathrm{pH}>6)$, the reduction of the bicarbonate ion becomes the predominant cathodic reaction ${ }^{3}$.

These electrochemical reactions are often accompanied by the formation of a film on the metal surface. This occurs when the $\mathrm{Fe}^{2+}$ and $\mathrm{CO}_{3}^{2-}$ concentrations exceed the solubility limit and precipitation of iron carbonate is initiated:

$\mathrm{Fe}^{2+}+\mathrm{CO}_{3}^{2-} \rightleftarrows \mathrm{FeCO}_{3}$ 
The properties of these films should be taken into account since the $\mathrm{FeCO}_{3}$ precipitate can act either in a protective or non-protective manner, depending on the specific conditions under which it forms.

At $\mathrm{pH}<7$, the carbonate ion $\left(\mathrm{CO}_{3}^{2-}\right)$ is a minority species, and the direct reduction of $\mathrm{HCO}_{3}^{-}$(Reaction 8) is an important factor in the formation of the $\mathrm{FeCO}_{3}$ films on the steel surface. The $\mathrm{FeCO}_{3}$ forms by the following equation:

$$
\mathrm{Fe}^{2+}+\mathrm{HCO}_{3}^{-} \rightleftarrows \mathrm{FeCO}_{3}+\mathrm{H}^{+}
$$

The overall reaction is:

$$
\mathrm{CO}_{2}+\mathrm{H}_{2} \mathrm{O}+\mathrm{Fe} \rightleftarrows \mathrm{FeCO}_{3}+\mathrm{H}_{2}
$$

Some authors ${ }^{4,12,16,17}$ emphasize the importance of the evaluation of the specific nature of the film formed under a given set of conditions, as these conditions can affect the type of film formed on the steel. In general, the precipitation of an iron carbonate film on the surface of mild steel significantly reduces the corrosion rate. Due to its nonuniform nature, however, in some cases this carbonate can contribute to localized corrosion.

The corrosion rate is closely dependent on a series of parameters such as temperature, pressure, $\mathrm{pH}$ and steel composition. Nešić and Nordesveen ${ }^{16}$ proposed a theoretical model of carbon dioxide corrosion in which the main focus was on the factors which influence $\mathrm{FeCO}_{3}$ film formation and the effect that these films have on the overall $\mathrm{CO}_{2}$ corrosion process. These authors suggested that corrosion rates are not, in fact, closely associated simply with the thickness of the protective film, but rather with its degree of coverage or homogeneity on the metal surface. This film can partially cover the surface and consequently block only a portion of the exposed metal or, in some cases, it can homogeneously cover the entire surface of steel, in which case it can prevent further dissolution. These authors also reported that, additionally, the processes which occur during corrosion underneath this film, at its interface with the metal, can induce the formation of voids or holes in the film. The rate at which such voids appear is important for determining what type of film will form. Via the film's density, porosity and thickness, the degree to which it may act as a protective barrier can be determined. With the aid of their model, they also confirmed that high levels of $\mathrm{pH}$, temperature, partial pressure of $\mathrm{CO}_{2}$ and $\mathrm{Fe}^{2+}$ concentration associated with a low formation rate of the above mentioned voids can favour the formation of a protective iron carbonate film.

The object of the present work was to study the stability of iron carbonate films formed on longitudinal welded joints of an API5L X70 and API5L X80 steel pipes at various temperatures $\left(25^{\circ} \mathrm{C}, 40{ }^{\circ} \mathrm{C}, 60^{\circ} \mathrm{C}\right.$ and $\left.80{ }^{\circ} \mathrm{C}\right)$ in a $1 \% \mathrm{wt}$ $\mathrm{NaCl}$ test solution which had been bubbled with $\mathrm{CO}_{2}$ for 48 hours. The samples were subjected to two related test conditions: either completely immersed in the solution or exposed to the adjacent vapour phase. This work is a study on a new and current theme, where the novelty resides in the development of tests with specimens simultaneously placed in a liquid and vapor phase containing $\mathrm{CO}_{2}$. It was found that the process by which the corrosion product layer formed on the surface of those samples immersed in the $\mathrm{CO}_{2}$ containing fluid was different from that of the samples exposed to the vapour phase. The resulting films of corrosion products were analyzed by scanning electron microscopy (SEM) and X-Ray Diffraction (XRD).

\section{Experimental Procedure}

Samples of the tube wall and welded joints comprising three regions (weld metal, heat affected zone and base metal) were taken from the longitudinal welded joint of the pipe which had been welded by the Tandem arc submerged welding process ${ }^{18}$. The chemical composition of the base metal and weld metal, welding parameters and details of the microstructural characterization are shown in Table 1, 2, and Figure 1, respectively. The specimen geometry and dimensions ( $2.5 \mathrm{~cm}$ in length, $1.5 \mathrm{~cm}$ wide and $0.2 \mathrm{~cm}$ thick) are detailed in Figure 2.

Oxides and impurities were removed from the samples' surfaces by progressively finer grinding to 600 grade abrasive. The specimens were washed with neutral detergent and deionised water, and degreased with acetone in accordance with the procedures specified in the ASTM G1-03 standard ${ }^{19}$.

Three sets of samples of both base metal and welded joint material were tested for each of the steels grades (X70 and X80) under both, the fully immersed and the vapour phase conditions to corroborate reproducibility.

Table 1. Chemical compositions of the base metal (BM) and weld metal (WM) in wt\%.

\begin{tabular}{lccccccccccc}
\hline Material & $\mathbf{C}$ & $\mathbf{M n}$ & $\mathbf{S i}$ & $\mathbf{N b}$ & $\mathbf{T i}$ & $\mathbf{C r}$ & $\mathbf{M o}$ & $\mathbf{V}$ & $\mathbf{P}$ & $\mathbf{S}$ & $\mathbf{N}$ \\
\hline BM X70 & 0.06 & 1.55 & 0.18 & 0.055 & 0.017 & 0.02 & - & - & 0.010 & 0.002 & 0.0071 \\
BM X80 & 0.04 & 1.85 & 0.18 & 0.073 & 0.016 & 0.32 & 0.03 & - & 0.024 & 0.004 & 0.0040 \\
WMX70 & 0.06 & 1.57 & 0.34 & 0.026 & 0.011 & 0.06 & 0.19 & 0.046 & 0.00825 & 0.0034 & - \\
WM X80 & 0.07 & 1.91 & 0.23 & 0.045 & 0.0125 & 0.16 & 0.29 & 0.0055 & 0.017 & 0.0045 & - \\
\hline
\end{tabular}

Table 2. Welding Parameters of API X70 and X80 Steels.

\begin{tabular}{lcccc}
\hline \multicolumn{1}{c}{ Material } & Current $(\mathbf{A})$ & Voltage $(\mathbf{V})$ & Speed (in/min) & Heat Input rate $(\mathbf{K J} / \mathbf{c m})$ \\
\hline X70 Inside & 990 & 38 & 62 & 43.4 \\
X70 Outside & 1020 & 39 & 62 & 45.5 \\
X80 Inside & 870 & 38 & 70 & 33.4 \\
X80 Outside & 980 & 40 & 69 & 39.6 \\
\hline
\end{tabular}


All tests were conducted at atmospheric pressure in an acrylic cell containing $1 \%$ wt $\mathrm{NaCl}$ solution (value required by the research centre which conducted the tests to simulate the sodium chloride content in extraction water). The test temperatures applied were $25^{\circ} \mathrm{C}, 40{ }^{\circ} \mathrm{C}, 60{ }^{\circ} \mathrm{C}$ and $80^{\circ} \mathrm{C}$. Deoxygenation of the solution was carried out by $\mathrm{N} 2$ purge for at least 1 hour and $99.9 \%$ purity $\mathrm{CO} 2$ was bubbled through the solution until saturation. The saturated solution was transferred to the test cell and heated to the test temperature. All tests were conducted for a period of
48 hours and $\mathrm{CO} 2$ bubbling was and kept throughout the test. The specimens were placed in the testing cell in one of two different positions: either fully immersed in the solution or completely exposed to the adjacent vapour phase (Figure 3 ).

After exposure to the test environment, the samples were removed from the solution. Corrosion products were removed from the specimen surfaces by scrubbing with a non-metallic bristle brush or, if necessary, mechanically with a brush metal, taking care not to remove metal surface. After the removal, the specimens were cleaned (mechanically or
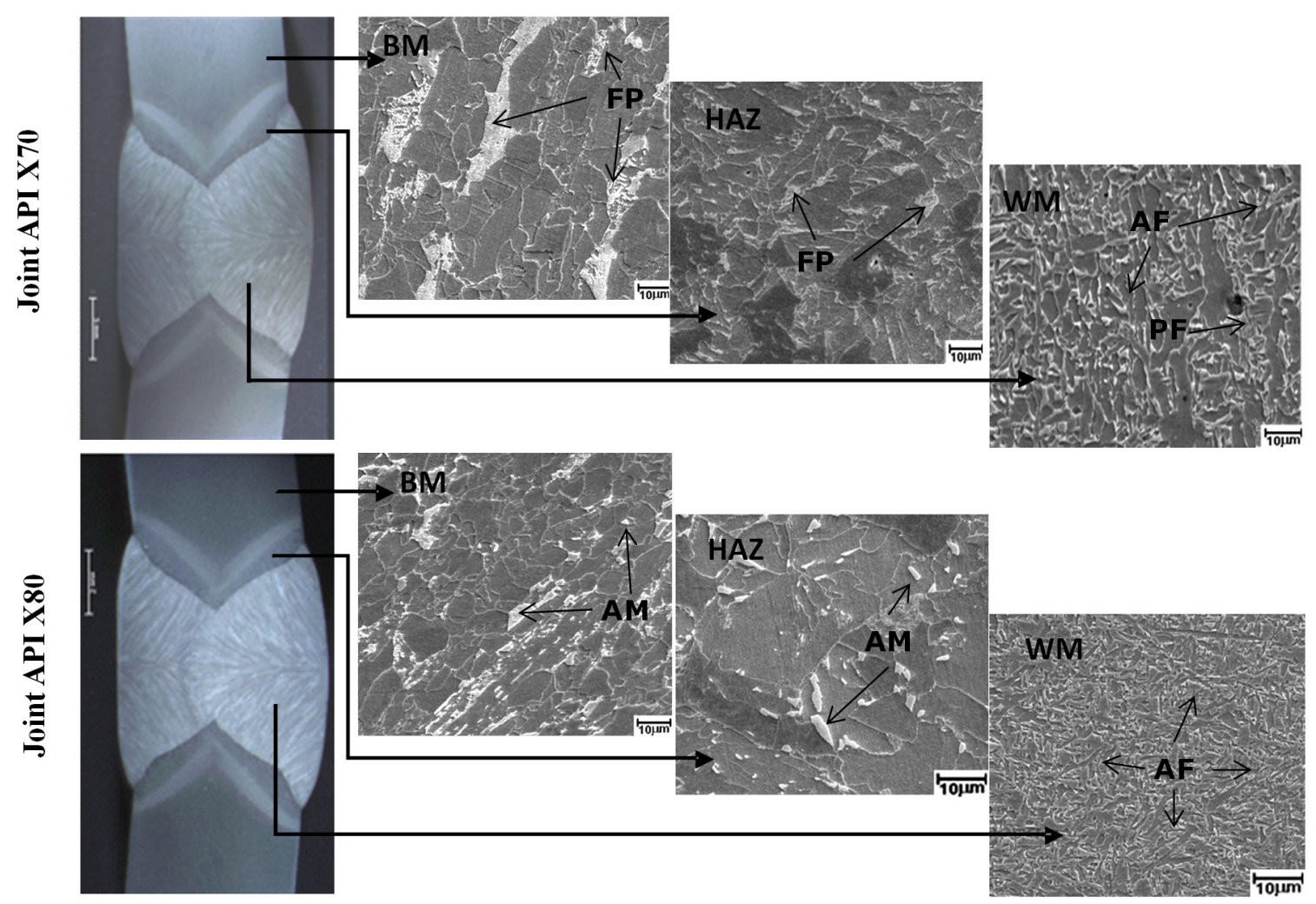

Figure 1. Representative microstructures of base metal, HAZ and weld metal.

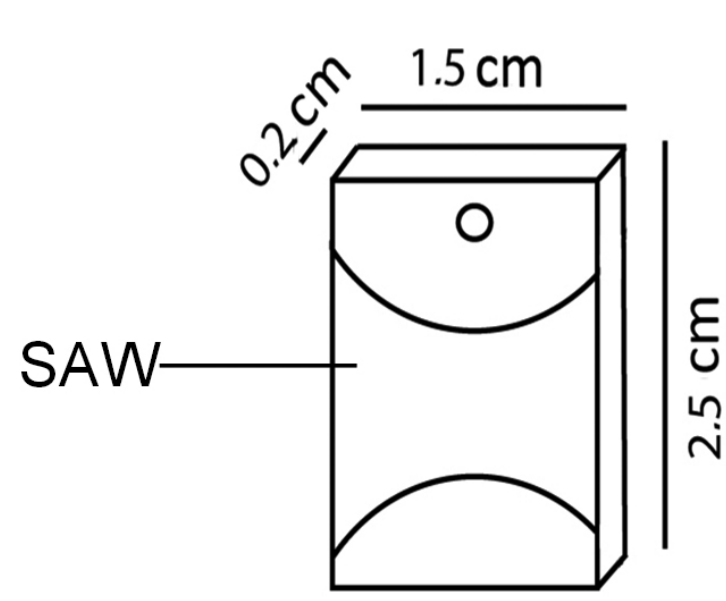

Figure 2. Dimensions of specimens of the SAW welded joint.

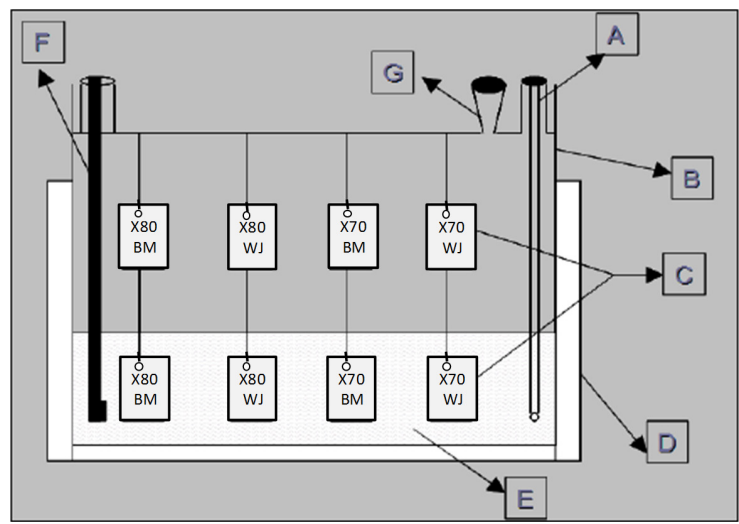

Figure 3. Schematic representation of the immersion test, where (A) thermometer, (B) cell, (C) samples (immersed and vapour), (D) thermostatically controlled bath, (E) $1 \%$ wt. $\mathrm{NaCl}$ solution, (F) gas inlet, (G) gas outlet, BM (Base Metal), WJ (Welded Joint). 
chemically with Clark solution as described in the standard ASTM G1-03 ${ }^{[19]}$ ), dried and re-weighed. The corrosion rate was then calculated as an average of the results obtained from three different coupons, using the following equation ${ }^{19}$ :

$$
T_{c}=\frac{8.76 \cdot 10^{4} \cdot \Delta M_{c}}{A \cdot t \cdot \rho}
$$

Where $T_{c}=$ Corrosion Rate in $\mathrm{mm} /$ year, $\Delta M_{c}=$ corrected mass loss in $\mathrm{g}, A=$ Area in $\mathrm{cm}, t=$ time in hours and $\rho=$ specific mass in $\mathrm{g} / \mathrm{cm}^{3}\left(7,85 \mathrm{~g} / \mathrm{cm}^{3}\right)$.

Phase analysis of the corrosion products scale was performed using X-ray diffraction (XRD) in a Siemens $\mathrm{D} 5000$ diffractometer, using $\mathrm{Cu}-\mathrm{K} \alpha$ radiation. The corrosion product in powder form of two tested samples was collected in a container for immediate analysis of elements and compounds by X-ray diffraction. The morphology of the surface corrosion products layer was studied by scanning electron microscopy (SEM) using a DSM 960 ZEISS microscope.

\section{Results and Discussion}

Figure 1 shows that the API5L X70 base metal and HAZ exhibited ferritic-pearlitic (FP) microstructure, whereas the microstructure of the weld metal was basically acicular ferrite (AF), polygonal ferrite (PF) and pro-eutectoid ferrite (PEF) located at grain boundaries. The API5L X80 base

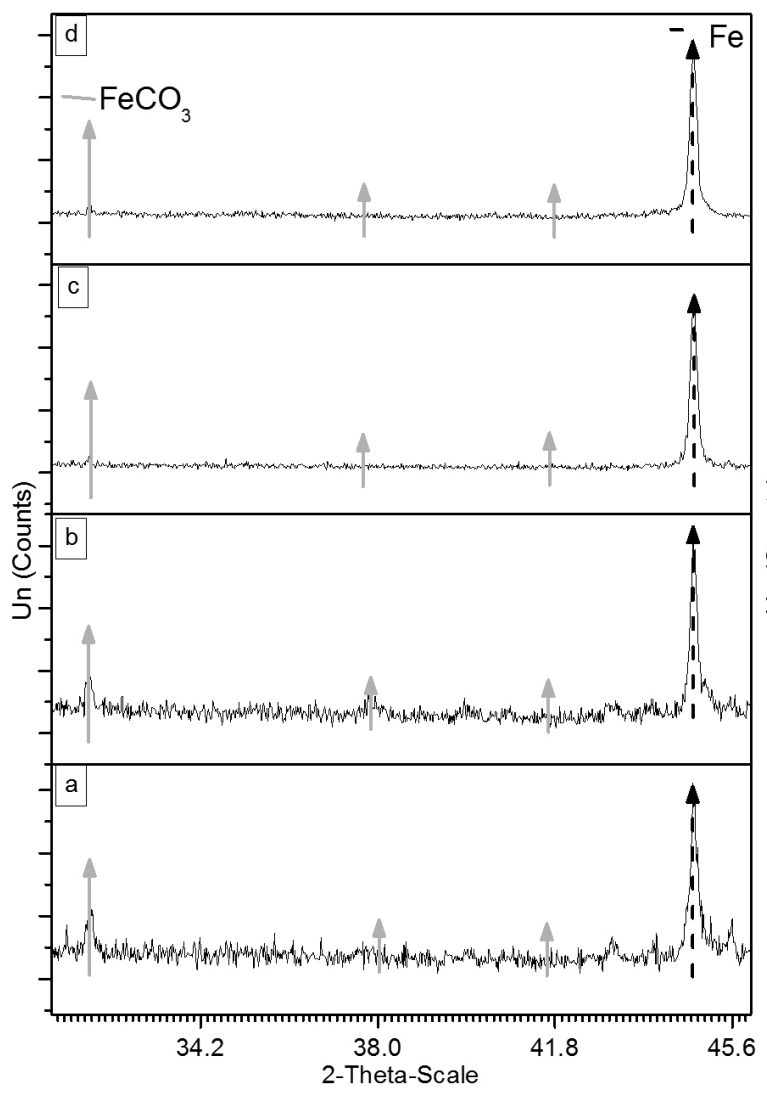

metal and HAZ exhibited ferrite with martensite-austenite (MA) microconstituent microstructure and the weld metal had an acicular ferrite microstructure.

Figure 4 shows the characteristic XRD patterns for specimens of the corrosion products obtained and Table 3 shows the results of a quantitative analysis performed using the Rietveld method and Bruker's TOPAS 3.0 software. These included samples corresponding to the base metal and the welded joint of each of the two steels, both for the fully immersed condition (in the solution at room temperature) and for exposure in the vapour phase at $60{ }^{\circ} \mathrm{C}$. At this temperature it can be seen in Figure 5 that the iron carbonate layer appears to have formed more readily on the base metal and welded joint of the API5L X70 than in the case of the API5L X80 steel specimens. Similar behaviour was also observed for other test temperatures.

Mass loss measurements (Figure 6) indicated that, in general, the corrosion rate increased with increasing temperature.

For the API5L X80 steel (which exhibited a ferrite-MA microstructure) subjected to the immersed condition (Figure 6), the corrosion rate increased with temperature, from $25^{\circ} \mathrm{C}$ to $80^{\circ} \mathrm{C}$. By contrast, the corrosion rate for the API5L X70 steel (ferrite-pearlite microstructure) increased with temperature up to $60{ }^{\circ} \mathrm{C}$, but subsequently showed a tendency to decrease at $80^{\circ} \mathrm{C}$. It is important to point out that

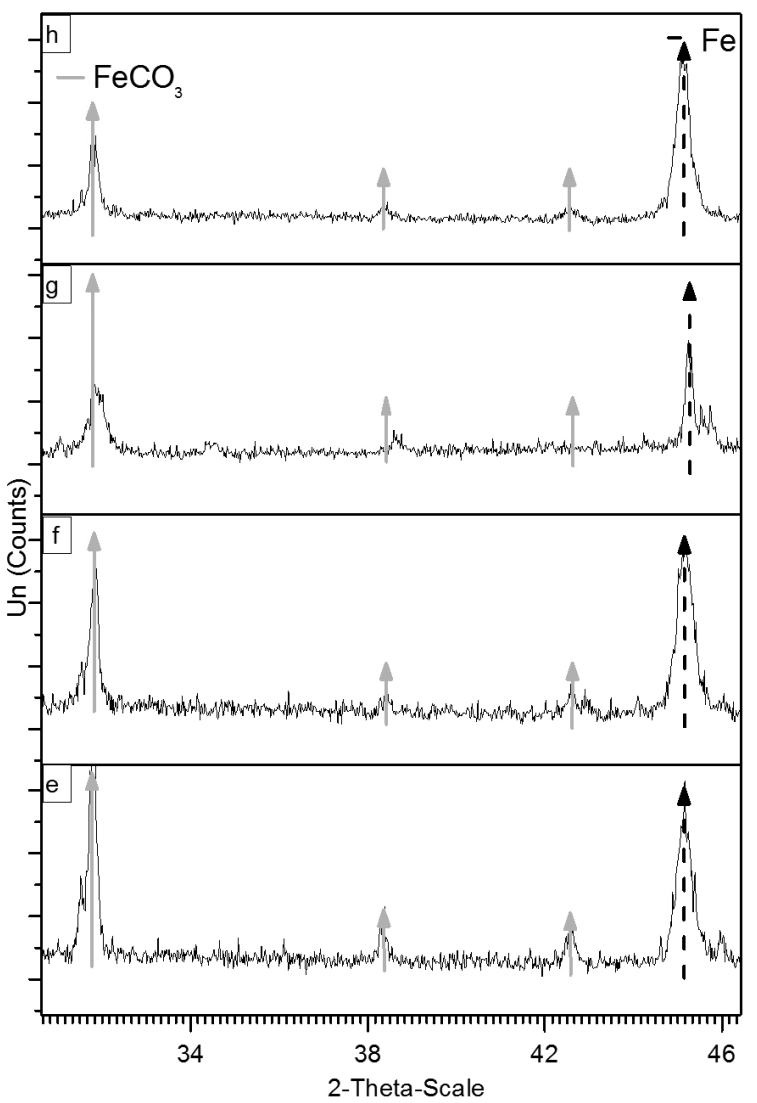

Figure 4. XRD patterns of the specimens immersed in the solution (I) at room temperature: (a) BMIX70, (b) WJIX70, (c) BMI X80, (d) WJIX80 and vapour phase (V) at $60^{\circ} \mathrm{C}$ : (e) BMVX70, (f) WJVX70, (g) BMVX80, (h) WJV X80. 
in the temperature range from $40{ }^{\circ} \mathrm{C}$ to $60{ }^{\circ} \mathrm{C}$ the corrosion rate was almost constant for all the conditions studied.

In the vapour phase (Table 4 and Figure 7), no significant differences in the corrosion rate were observed in the temperature range of $25^{\circ} \mathrm{C}$ to $60{ }^{\circ} \mathrm{C}$, with the exception of the API51 X70 ferritic-perlitic base metal, for which the corrosion rate was found to be lower in the temperature range of $40^{\circ} \mathrm{C}$ to $60{ }^{\circ} \mathrm{C}$, as shown on the insert of the Figure 7 . No corrosion product layer formation was evident for any of the samples tested at $25^{\circ} \mathrm{C}$.

In general, for chemical reactions, the corrosion rate increases with temperature since the temperature changes

Table 3. Quantification of corrosion product by XRD.

\begin{tabular}{ccc}
\hline Material & $\mathrm{Fe}-\mathrm{CCC}(\%)$ & $\mathrm{FeCO}_{3}(\%)$ \\
\hline $\mathrm{X} 70 \mathrm{BMI}-25{ }^{\circ} \mathrm{C}$ & 58.8 & 41.2 \\
$\mathrm{X} 70 \mathrm{WJI}-25{ }^{\circ} \mathrm{C}$ & 73.4 & 26.6 \\
$\mathrm{X} 80 \mathrm{BMI}-25{ }^{\circ} \mathrm{C}$ & 92.7 & 7.3 \\
$\mathrm{X} 80 \mathrm{WJI}-25{ }^{\circ} \mathrm{C}$ & 96.8 & 3.2 \\
$\mathrm{X} 70 \mathrm{BMV}-60{ }^{\circ} \mathrm{C}$ & 21.2 & 78.8 \\
$\mathrm{X} 70 \mathrm{WJV}-60{ }^{\circ} \mathrm{C}$ & 31.7 & 68.3 \\
$\mathrm{X} 80 \mathrm{BMV}-60{ }^{\circ} \mathrm{C}$ & 45.2 & 54.8 \\
$\mathrm{X} 80 \mathrm{WJIV}-60^{\circ} \mathrm{C}$ & 53.9 & 46.1 \\
\hline
\end{tabular}

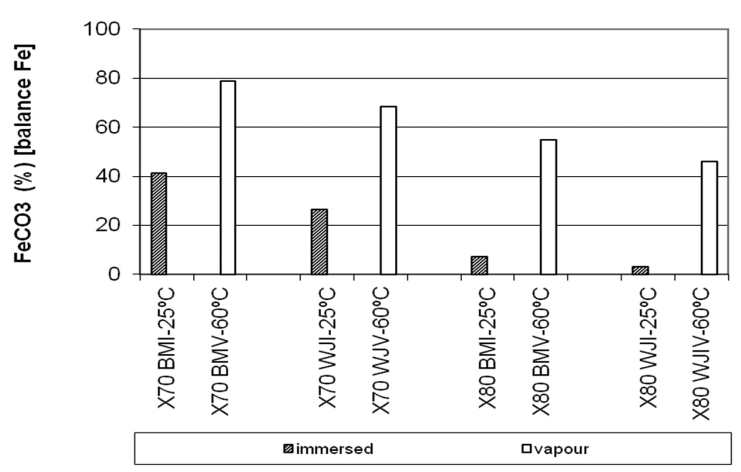

Figure 5. Relative \% of $\mathrm{FeCO} 3$ (balance $\mathrm{Fe}$ ) in the corrosion products as determined from the XRD data (BM-base metal, WJwelded joint, I-immersed, V-vapour).

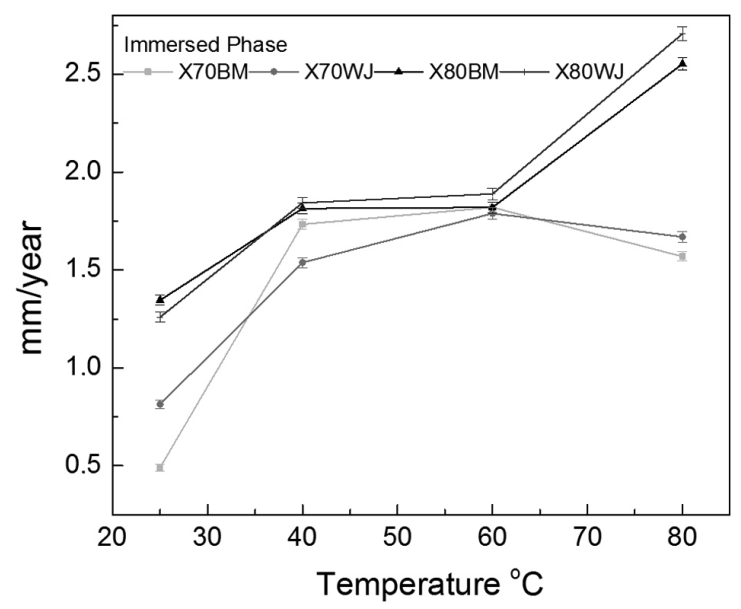

Figure 6. Corrosion rate of the fully immersed samples. the kinetics parameter ${ }^{20}$ and, as a consequence, it increases the corrosion rate. An indirect consequence of this is the occurrence of changes in the metal surface, reducing $\mathrm{CO}_{2}$ solubility and decreasing the cathodic process by increasing the $\mathrm{CO}_{2}$ diffusion coefficient. Iron carbonate solubility decreases with increasing temperature, and the consequent precipitation of iron carbonate is a significant factor in corrosion assessment ${ }^{21}$.

In the present study, the carbonate film formed at higher temperatures (above $60{ }^{\circ} \mathrm{C}$ ) is more stable and affords greater protection, reducing the corrosion rate. This is a possible explanation for the behaviour of corrosion rates above $60{ }^{\circ} \mathrm{C}$ for the base metal and welded joint of API5L X70 steel as seen in Figure 6. In the case of API5L X80 steel, although the film formed at $60{ }^{\circ} \mathrm{C}$ was more stable, the microstructural characteristics did not allow for a good anchor of this protective film on the surface of the specimen.

In the temperature range of $50{ }^{\circ} \mathrm{C}$ to $70{ }^{\circ} \mathrm{C}$ there is a change in the mechanism of the $\mathrm{CO}_{2}$ corrosion process that can mask the diffusive process, and a mixed mechanism of corrosion attack is established where there is a competition between mass and charge transfer ${ }^{22}$. This is a possible explanation why the corrosion rate does not show significant changes between $40{ }^{\circ} \mathrm{C}$ to $60{ }^{\circ} \mathrm{C}$ for both steels.

With regard to the difference in the microstructure of the metal substrate, the API5L X70 steel has a ferritepearlite microstructure, whereas the API5L X80 has a ferritic microstructure with martensite-austenite (MA) microconstituent. These differences affect not only the mechanical properties of the steel but also its corrosion rate $e^{4,12,17}$. The literature indicates that growth of an $\mathrm{FeCO}_{3}$ film is facilitated in steels with a ferrite-pearlite structure due to better anchorage of the carbonate deposits which adhere to

Table 4. Corrosion rates in mm/year, vapor phase.

\begin{tabular}{ccccc}
\hline $\begin{array}{c}\text { Temperature } \\
{ }^{\circ} \mathbf{C}\end{array}$ & $\begin{array}{c}\text { API X70 } \\
\text { BM }\end{array}$ & $\begin{array}{c}\text { API X70 } \\
\text { WJ }\end{array}$ & $\begin{array}{c}\text { API X80 } \\
\text { BM }\end{array}$ & $\begin{array}{c}\text { API X80 } \\
\text { WJ }\end{array}$ \\
\hline 25 & 0.107 & 0.102 & 0.067 & 0.098 \\
40 & 0.0012 & 0.027 & 0.029 & 0.033 \\
60 & 0.052 & 0.091 & 0.079 & 0.106 \\
80 & 0.510 & 0.631 & 0.504 & 0.813 \\
\hline
\end{tabular}

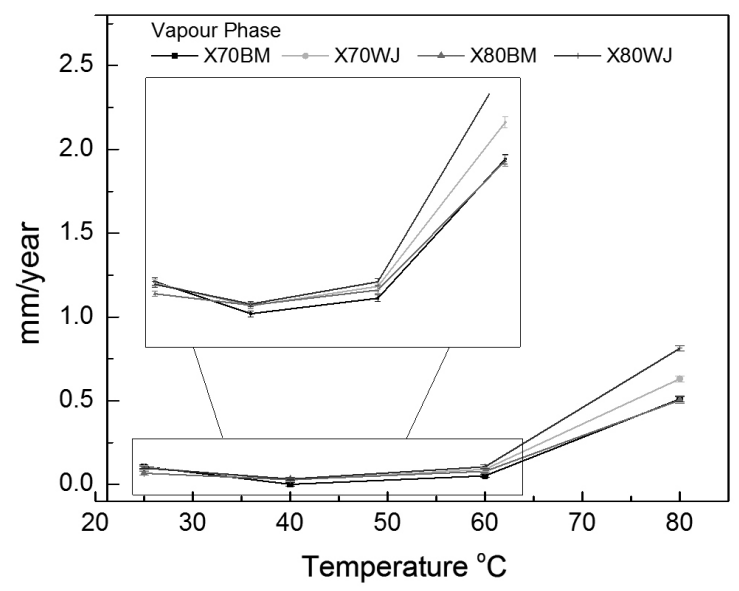

Figure 7. Corrosion rate of the vapour phase. 
the metal surface ${ }^{5,23-26}$. The explanation is based on the fact that ferrite located within the pearlitic matrix is dissolved and the deposit of carbonate is thus anchored between the remaining plates of cementite exposed at the surface.

$\mathrm{Li}$ et $\mathrm{al}^{5}$, in their work with on API X65 steel exposed to $\mathrm{CO}_{2}$ containing environments, described several stages of the corrosion process. In the first stage, the ferrite in the steel's microstructure, exposed at the surface, was dissolved, leaving a "skeletal" structure consisting of the undissolved cementite. This structure was reported to provide more effective anchoring of the precipitate layer which subsequently formed. As the process progressed, the concentrations of $\mathrm{Fe}^{2+}$ and $\mathrm{CO}_{3}^{2-}$ ions were observed to reach a level of supersaturation and, since these species had exceeded the solubility limit, cubic iron carbonate crystals were precipitated on the surface of the steel. As this scale was not compact enough to prevent further corrosion, the $\mathrm{CO}_{3}^{2-}$ and $\mathrm{HCO}_{3}^{-}$ions were able to penetrate between the crystals and reach the substrate to react with the metal. Further precipitation continued and dendritic growths exhibiting tropism developed, anchored on the cementite still attached to the metal surface. The formation of this dendritic scale caused stress in the outer scale layer, causing it to crack. Since the porous dendritic scale was also not effective in preventing ions from reacting with the metal, the corrosion process continued. Subsequently, however, the inner scale was observed to start to become thicker and denser, thereby protecting the surface from the solution. The formation of the $\mathrm{FeCO}_{3}$ layer eventually led to a global reduction of the rate of corrosion.

Crolet et al. ${ }^{23}$ showed that a thin, porous ("empty") layer of the $\mathrm{Fe}_{3} \mathrm{C}$ in contact with the steel (analogous to the "skeletal" structure of undissolved cementite mentioned above) is sufficient to cause so-called internal acidification, thereby increasing the corrosion rates due to the formation of a non-protective $\mathrm{FeCO}_{3}$ film on the steel. If a sufficiently high iron concentration exists in the test solution when the steel sample is immersed, then the $\mathrm{FeCO}_{3}$ can readily precipitate on the metal, and the resulting layer is protective in nature. By contrast, if the iron concentration increases only after the initial phase of corrosion, the exposure conditions lead to the formation of an "empty" $\mathrm{Fe}_{3} \mathrm{C}$ layer, resulting in internal acidification, and a non-protective film is formed.

In the case of steel with a martensitic-bainitic microstructure, the carbide particle distribution is of a less continuous and less ordered nature, rendering it less efficient in anchoring deposits on the surface of the metal ${ }^{9,24-26}$. Additionally, when welds are present, the microstructure of the weld metal is typically acicular ferrite, which becomes cathodic relative to the base metal when exposed to the corrosive solution. The microstructures which result from welding under these conditions can thus lead to an acceleration of the process and result in preferential weld corrosion (PWC) phenomena as well as the localized increase in hardness, grain size and the presence of other aligned phases ${ }^{6}$.

As mentioned above, the adhesion of the $\mathrm{FeCO}_{3}$ film and the degree to which it can behave in a protective manner are related to the presence of $\mathrm{Fe}_{3} \mathrm{C}$ in the steel since, under certain circumstances, the cementite phase can anchor the film on the substrate. The distribution, morphology and size of the carbides present in the steel are thus important factors ${ }^{4,12,11,24}$. The pearlitic cementite in the API5L X70 steel was present as continuous lamella within the extensive pearlite colonies. Even after significant anodic dissolution of the adjacent pearlitic ferrite, these lamellar plates remained firmly attached within the steel surface. Furthermore, this anodic dissolution of the ferrite during the corrosive process also increased the local concentration of iron ions, which, in turn, favoured the precipitation of an iron carbonate film in the presence of the $\mathrm{H}_{2} \mathrm{CO}_{3}$ dissolved in the solution.

For all samples exposed to the vapour phase, an iron carbonate layer formed at all test temperature, with the exception of room temperature. This process receives relatively little attention in the literature. The results obtained in the present study for the vapour phase (Figure 7) indicated an increase in corrosion rate with temperature above $60^{\circ} \mathrm{C}$. It was observed that at $25{ }^{\circ} \mathrm{C}$ no film was formed and most of the films formed under these conditions were observed to be porous and discontinuous and thus not protective in nature. An increase in temperature within the range studied would effectively increase the density of the vapour phase and therefore deposition of liquid on the surface of the steel. As a consequence it would have contributed for a formation of a more efficient layer on the surface.

Within those areas for which the corrosive medium was deposited from the vapour, the $\mathrm{CO}_{2}$ corrosion process would occur by the mechanisms described by Li et al. ${ }^{5}$ and Crolet et $\mathrm{al}^{23}$. The results of the present study indicate, however, that the quantity of solution present on the metal surface was insufficient to permit the formation of protective iron carbonate layers. On the contrary, discontinuous, porous layers were observed, which contributed to increased localized corrosion.

SEM observations showed that the temperature which had most favoured the formation of a $\mathrm{FeCO}_{3}$ film was $60^{\circ} \mathrm{C}$, both for the specimens immersed in the test solution and for those exposed to the adjacent vapour phase. The presence of $\mathrm{FeCO}_{3}$ on the surface of the steel after exposure to the test media was confirmed by the SEM analysis as shown in Figure 8 (in this example, the film observed was that formed on the surface of one of the immersed steel specimens). Alawadhi and Robinson ${ }^{6}$, reported that the stability of the protective iron carbonate layers formed increased with test temperatures above $60^{\circ} \mathrm{C}$. By contrast, the mass loss results of the present study indicate that the formation of a $\mathrm{FeCO}_{3}$ layer can in fact increase localized corrosion when the layers formed are discontinuous and porous. When the samples were totally immersed in the solution containing $\mathrm{CO}_{2}$, the $\mathrm{FeCO}_{3}$ layer was observed to cover the entire surface. In the vapour phase, however, for otherwise similar conditions, the film was observed to be present only in some regions of the sample surface, as shown in Figures 9a, b.

At $60{ }^{\circ} \mathrm{C}$, the $\mathrm{pH}$ was observed to be higher than 6 and the percentage of $\mathrm{HCO}_{3}^{-}$in aqueous solutions was higher under these conditions. Dissolved $\mathrm{HCO}_{3}{ }^{-}$ions are dominant depolarizers, and deprotonated to form the $\mathrm{CO}_{3}^{2-}$ (Reaction 8), then the iron carbonate is formed according to Reaction 10. According to Crolet et al. ${ }^{23}$, at $\mathrm{pH} 6$, the transport capacity of acidity via the highly mobile $\mathrm{H}^{+}$ (or $\mathrm{H}_{3} \mathrm{O}^{+}$) ions is negligible compared to the indirect effect 
of diffusion of quantities of $\mathrm{mM} / \mathrm{L}$ of dissolved $\mathrm{CO}_{2}$, even though mobility of the latter is low and the kinetics of the final hydration of $\mathrm{CO}_{2}$ and dissociation of $\mathrm{H}_{2} \mathrm{CO}_{3}$ are slow. Thus, to conserve a realistic physical meaning for each solubility product, they are written systematically in terms of the majority independent species, which can be transported directly. $\mathrm{HCO}_{3}^{-}$ions are concentrated enough to be transported directly, but $\mathrm{CO}_{3}^{2-}$ ions are mainly formed or removed locally by a chemical reaction. From this local equilibrium between $\mathrm{HCO}_{3}^{-}$and $\mathrm{CO}_{3}^{2-}$, the solubility equation of Reaction (10) can be written as follows:

$\left[\mathrm{Fe}^{2+}\right]+\left[\mathrm{HCO}_{3}^{-}\right]=\mathrm{K}_{2} \mathrm{~K}_{s}\left[\mathrm{H}^{+}\right]=K\left[\mathrm{H}^{+}\right]$

In the above equation, $\mathrm{K}_{2}$ is the equilibrium constant for the second dissociation of $\mathrm{H}_{2} \mathrm{CO}_{3}$. At a given $\mathrm{pH}$, the $\mathrm{HCO}_{3}^{-}$ anion then appears mathematically in Equation 12 as the precipitable anion leading to the formation of solid $\mathrm{FeCO}_{3}$, with a corresponding solubility constant equal to $\mathrm{K}\left[\mathrm{H}^{+}\right]$.

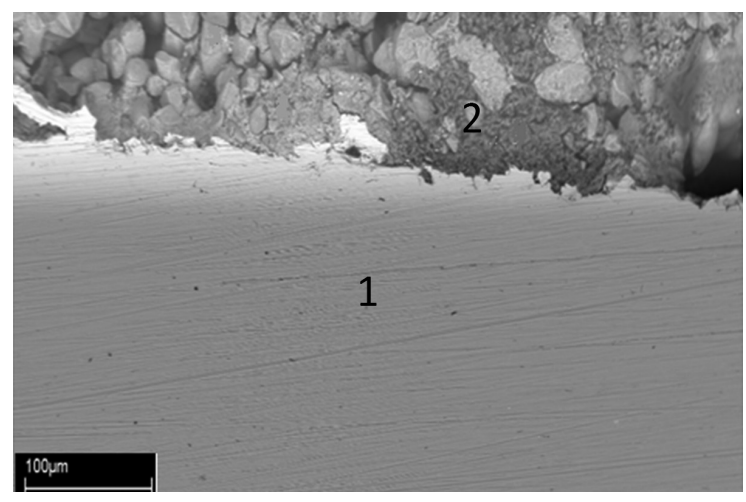

Figure 8. API $5 \mathrm{~L} \mathrm{X80} \mathrm{steel,} \mathrm{tested} \mathrm{under} \mathrm{fully} \mathrm{immersed} \mathrm{conditions}$ $\left(1 \% \mathrm{NaCl}, \mathrm{pH} 6.5,60^{\circ} \mathrm{C}\right)$, where 1-base metal and 2- Iron Carbonate film.

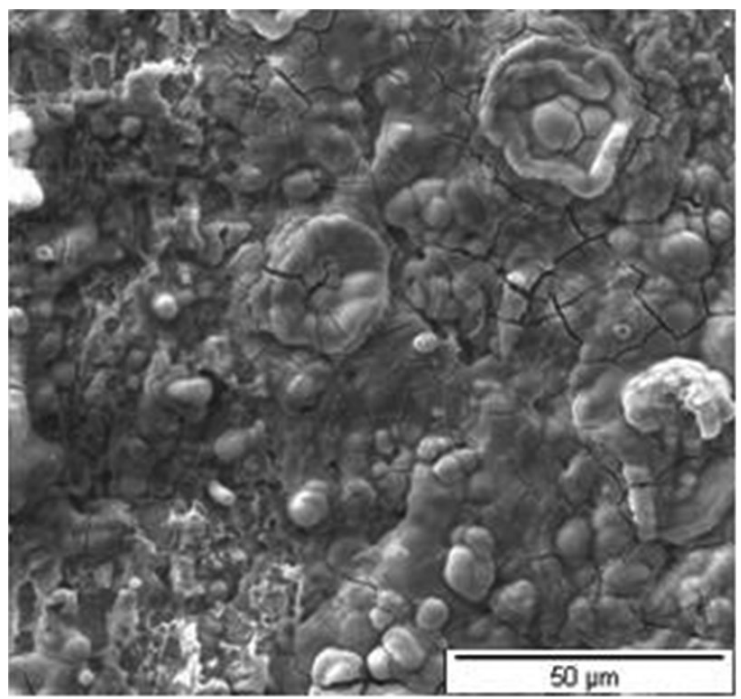

(a)
In the case of room temperature testing, the $\mathrm{pH}$ was seen to be lower, at about 4.5, and the principal species to form during the precipitation of the $\mathrm{FeCO}_{3}$ film was $\mathrm{H}_{2} \mathrm{CO}_{3}$. At $\mathrm{pH}=4$, both $\mathrm{H}_{2} \mathrm{CO}_{3}$ and $\mathrm{HCO}_{3}^{-}$are present in large quantities, therefore, either could participate in the solid transformation leading to iron carbonate ${ }^{27}$. This results in the formation of hydrocarbonates that are unstable and decompose with time, in successive reactions:

$$
\begin{aligned}
& \mathrm{Fe}+2 \mathrm{H}_{2} \mathrm{CO}_{3} \rightarrow \mathrm{Fe}\left(\mathrm{HCO}_{3}\right)_{2}+\mathrm{H}_{2} \\
& \mathrm{Fe}\left(\mathrm{HCO}_{3}\right)_{2} \leftrightarrows \mathrm{Fe}^{2+}+2 \mathrm{HCO}_{3}^{-} \\
& \mathrm{HCO}_{3}^{-} \rightleftarrows \mathrm{H}^{+}+\mathrm{CO}_{3}^{2-} \\
& \mathrm{Fe}^{2+}+\mathrm{CO}_{3}^{2-} \rightarrow \mathrm{FeCO}_{3}
\end{aligned}
$$

It was observed visually and confirmed by SEM analysis that for temperatures above $60{ }^{\circ} \mathrm{C}$ the iron carbonate scale decomposed more quickly than at lower temperatures. For the highest testing temperature $\left(80^{\circ} \mathrm{C}\right)$, a short time after the test was completed no iron carbonate scales was observed at all, with only a layer of oxide being detected on the specimen surface. This would contradict the findings presented by Heuer and Stubbins ${ }^{28}$, who studied the stability of $\mathrm{FeCO}_{3}$ films at temperatures of around $75^{\circ} \mathrm{C}$ using an XPS method. They found that "unripened" $\mathrm{FeCO}_{3}$ scales were formed at temperatures below $75{ }^{\circ} \mathrm{C}$, while more stable layers were formed at higher temperatures; the precipitate which formed at lower temperatures was unstable and quickly decomposed into $\mathrm{Fe}_{2} \mathrm{O}_{3}$ in air, by the following reactions:

$$
\mathrm{FeCO}_{3} \rightarrow \mathrm{FeO}+\mathrm{CO}_{2}
$$

After this decomposition, $\mathrm{Fe}_{2} \mathrm{O}_{3}$ may subsequently be formed, in the presence of $\mathrm{O}_{2}$.

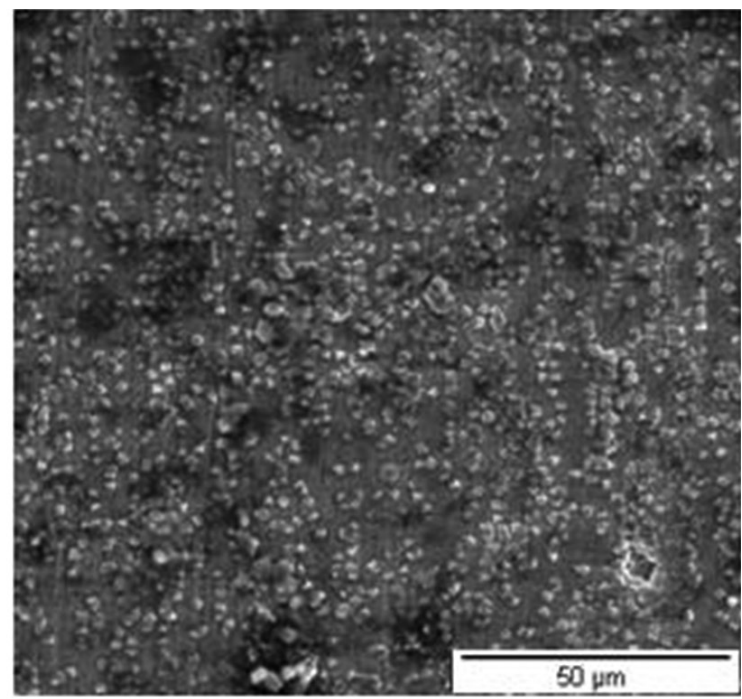

(b)

Figure 9. API 5L X80 Steel $\left(1 \% \mathrm{NaCl}, \mathrm{pH} 6.5\right.$, temperature $\left.60^{\circ} \mathrm{C}\right)$ comparing the surface films formed; (a) under fully immersed conditions and (b) exposed to the adjacent vapour phase. 
$4 \mathrm{FeO}+\mathrm{O}_{2} \rightarrow 2 \mathrm{Fe}_{2} \mathrm{O}_{3}$

Dugstad ${ }^{29}$ reported that the morphology and composition of the surface films which he studied varied according to the temperature at which they formed. Below $40{ }^{\circ} \mathrm{C}$, the surface films exhibited an open porous structure and were composed mainly of $\mathrm{Fe}_{3} \mathrm{C}$, with some $\mathrm{FeCO}_{3}$. $\mathrm{Fe}_{3} \mathrm{C}$ (cementite) is a phase which is already present in the steel in its non-oxidized state, and it accumulates on the surface of the steel when the metal surface is exposed to a corrosive medium provoking corrosion of the surrounding iron-rich matrix. The film produced at $60^{\circ} \mathrm{C}$ presented an inner porous region (adjacent to the metal surface) composed mainly of $\mathrm{Fe}_{3} \mathrm{C}$, and an outer region (adjacent to the solution) with a higher level of $\mathrm{FeCO}_{3}$. Nevertheless, this type of film was not observed to reduce the rate of corrosion. At $80^{\circ} \mathrm{C}$, however, a dense protective $\mathrm{FeCO}_{3}$ layer was formed on the steel, and this was found to decrease the corrosion rate, according to measurements taken at around 20-40h.

Differential thermal analysis (DTA) studies by Hebb et al. ${ }^{30}$ indicated that reagent grade $\mathrm{FeCO}_{3}$ is relatively unstable. They found that this iron carbonate begins decomposing at temperatures below $100{ }^{\circ} \mathrm{C}$, as shown in Reaction (17) above. After this initial decomposition, the resulting $\mathrm{FeO}$ may undergo an additional chemical reaction, depending on the surrounding environment. Reaction (19a) shows that, in the presence of oxygen, $\mathrm{FeO}$ transforms quickly into $\alpha-\mathrm{Fe}_{2} \mathrm{O}_{3}$, but Equation $19 \mathrm{~b}, \mathrm{c}$ indicate that in the absence of oxygen, it transforms into $\mathrm{Fe}_{3} \mathrm{O}_{4}$, if either $\mathrm{CO}_{2}$ or water vapour are present ${ }^{31}$.

$$
\begin{aligned}
& 4 \mathrm{FeO}+\mathrm{O}_{2} \rightarrow 2 \mathrm{Fe}_{2} \mathrm{O}_{3} \\
& 3 \mathrm{FeO}+\mathrm{CO}_{2} \rightarrow \mathrm{Fe}_{3} \mathrm{O}_{4}+\mathrm{CO} \\
& 3 \mathrm{FeO}+\mathrm{H}_{2} \mathrm{O} \rightarrow \mathrm{Fe}_{3} \mathrm{O}_{4}+\mathrm{H}_{2}
\end{aligned}
$$

Song et al. ${ }^{32}$ stress the importance of the temperature, as it exerts a strong influence on several relevant kinetic and thermodynamic factors. They observed that the thickness of the layer formed decreased with increasing temperature and decreasing saturation factor. Under these conditions, the authors observed lower corrosion rates for lower test temperatures. They explained this behaviour in terms of a reduced tendency for the metal surface to adsorb corrosive species at lower temperatures. At higher temperatures, however, it was noted that the system could enter into a zone of passivity and thus also exhibit a reduced corrosion rate.

Kinsella et al. ${ }^{33}$ used EIS and weight-loss measurement to study the influence of environmental factors on $\mathrm{CO}_{2}$ corrosion products scales formation. They found that the carbon dioxide corrosion products formed at high temperature and pressure gave better protection than those formed at low temperature and pressure. The protectiveness of these scales was a function of exposure time.

Figure 10 presents SEM micrographs of the API51 X70 steel base metal after removal of the $\mathrm{FeCO}_{3}$ film for samples which had been fully immersed in the test solution at $40^{\circ} \mathrm{C}$ and at $80{ }^{\circ} \mathrm{C}$. Localized corrosion was identified on the $40{ }^{\circ} \mathrm{C}$ test temperature sample by the presence of pitting in the metal surface, whereas uniform corrosion was observed for the $80{ }^{\circ} \mathrm{C}$ test samples.

Figure 11 shows a sequence of SEM micrographs of the surface of samples exposed to the vapour phase before removal of the corrosion products, and optical micrographs after subsequent removal of the resulting surface film. It can be observed that the degree of surface coverage by corrosion products increased with increasing test temperature. These products, however, did not cover the entire surface and evidence of accentuated metal dissolution was found, as seen on the steel surface after the removal of the surface film.

Once more, localized corrosion was observed for the samples tested at $40{ }^{\circ} \mathrm{C}$, and uniform corrosion at increased temperatures, as shown by the optical micrographs in Figure 11. Muñoz et al. ${ }^{7}$ studied the corrosion rate ofAPI5L X70 steel as a function of temperature using mass loss measurements and found that at lower temperatures the corrosion rate increased due to the continued formation of $\mathrm{Fe}^{2+}$. As the temperature was increased to about $60{ }^{\circ} \mathrm{C}$, the $\mathrm{FeCO}_{3}$ layer formed was more adherent to the surface and therefore more protective in nature. The authors showed the morphology of the corrosion damage using optical microscopy. It was found that at testing temperatures

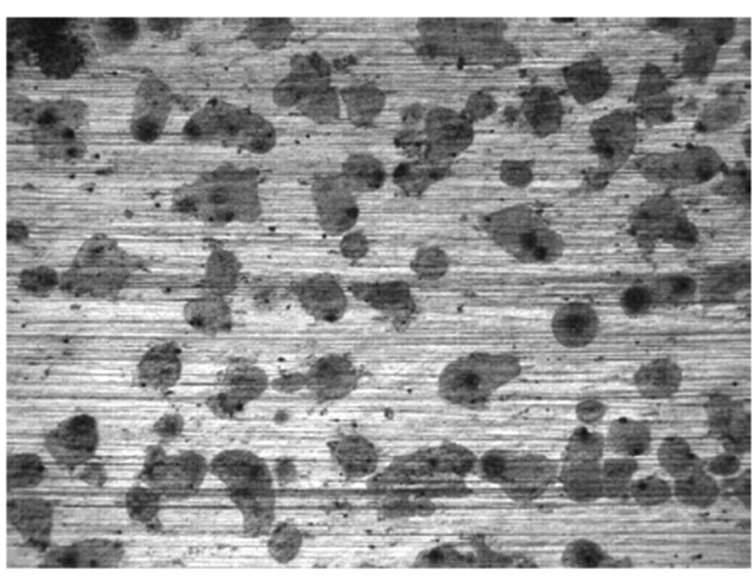

$40^{\circ} \mathrm{C}$

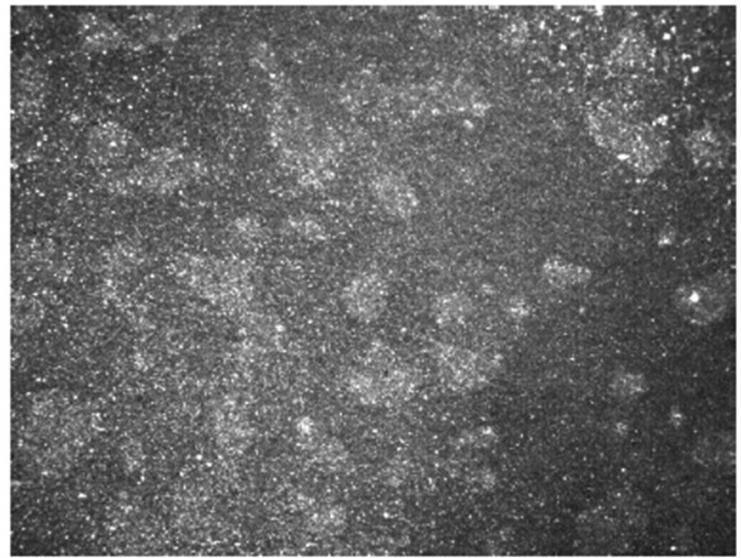

$80^{\circ} \mathrm{C}$

Figure 10. Optical Microscopy, at 50X, of the API X70 steel base metal surface after testing under fully immersed conditions. 


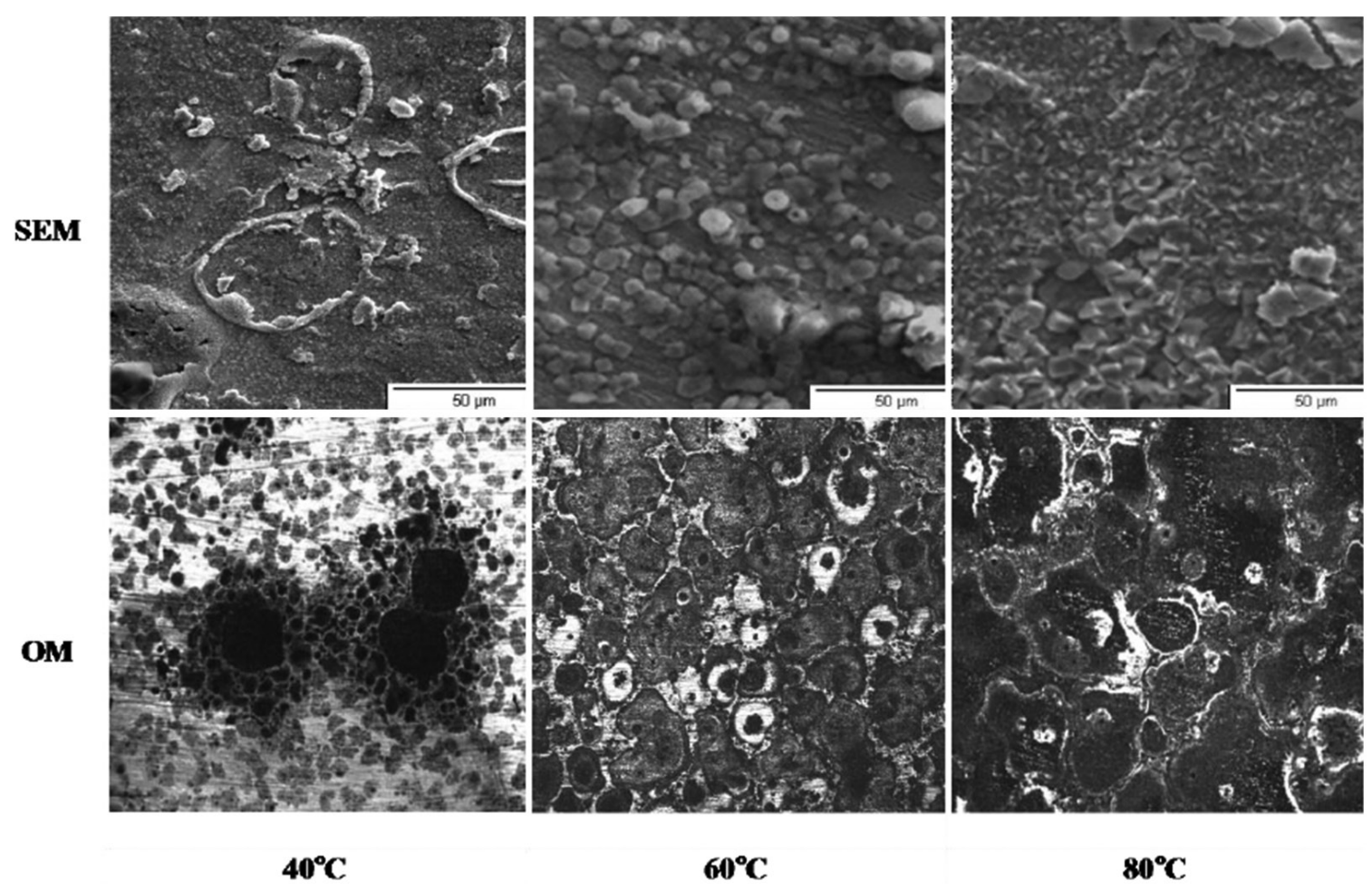

Figure 11. Samples observed after exposure to the vapor phase; SEM micrographs before removal of the corrosion products, and OM micrographs (at 50X) after subsequent removal of the resulting surface film.

between $25^{\circ} \mathrm{C}$ and $65^{\circ} \mathrm{C}$ localized corrosion was evident, while at $75{ }^{\circ} \mathrm{C}$ uniform corrosion was observed, similar to the results obtained in the present work. The temperature is therefore an important factor which significantly influences the precipitation and stability of the $\mathrm{FeCO}_{3}$ film. It was confirmed that at higher temperatures (around $80{ }^{\circ} \mathrm{C}$ ), the solubility of these films decreases, leading to effective scale formation, whereas at lower temperatures the dissolution of iron is faster than the precipitation of the film ${ }^{32-35}$.

\section{Conclusions}

Temperature is an important factor in the formation of $\mathrm{CO}_{2}$ corrosion products. It has a significant influence on the precipitation and stability of the $\mathrm{FeCO}_{3}$ film. Furthermore, a tendency for the corrosion rate to increase with increasing temperature was observed.

The iron carbonate layer formed on the surface of both steels tested was formed more readily at a temperature of $60{ }^{\circ} \mathrm{C}$ for all conditions studied (fully immersed in the test solution and exposed to the adjacent vapour phase).

For the samples which had been immersed in solution, the $\mathrm{FeCO}_{3}$ layer totally covered the steel surface. However, for those exposed to the adjacent vapour phase, the $\mathrm{FeCO}_{3}$ layer was observed to be porous and discontinuous.
The layer of iron carbonate film formed at higher temperatures $\left(80{ }^{\circ} \mathrm{C}\right)$ decomposed quickly when exposed to air, and the samples subsequently exhibited only a layer of oxide on the surface due the decomposition of $\mathrm{FeCO}_{3}$ into $\mathrm{Fe}_{2} \mathrm{O}_{3}$

The base metal and welded joint of the API5L X70 steel showed lower rates of corrosion in the range of $40{ }^{\circ} \mathrm{C}$ to $60{ }^{\circ} \mathrm{C}$ in the vapour phase and at $80^{\circ} \mathrm{C}$ for the fully immersed condition. This decrease of the corrosion rates was attributed to the formation of the more stable iron carbonate film at higher temperatures, which can afford greater protection to this steel.

The presence of $\mathrm{Fe}_{3} \mathrm{C}$ (from the steel microstructure) acted as the cathodic region and the ferrite as the anodic region, thus promoting the precipitation of the iron carbonate layer and better adherence to the metal surface.

For API5L X80 steel, reduction in the corrosion rate was not observed since the microstructural characteristics of this alloy did not allow a good anchor for the protective layer.

\section{Acknowledgements}

The authors wish to acknowledge the financial support of CNPq, CAPES, INT and CENPES - PETROBRAS. 


\section{References}

1. Zhao GX, Lu XH, Xiang JM and Hant Y. Formation Characteristic of $\mathrm{CO}_{2}$ Corrosion Products Layer of P110 Steel Investigated by SEM and Electrochemical Techniques. International Journal of Iron and Steel Research. 2009; 16(4):89-94. http://dx.doi. org/10.1016/S1006-706X(09)60067-4

2. Zhang Y, Pang X, Qua S, Li X and Gao K. Discussion of the $\mathrm{CO}_{2}$ Corrosion Mechanism Between Low Partial Pressure and Supercritical Condition. Corrosion Science. 2012; 59:186-197. http://dx.doi.org/10.1016/j.corsci.2012.03.006

3. Nazari MH, Allahkaram SR and Kermani MB. The Effects of Temperature and $\mathrm{pH}$ on the Characteristics of Corrosion Product in $\mathrm{CO}_{2}$ Corrosion of Grade X70 Steel. Materials \& Design. 2010; 31(7):3559-3563. http://dx.doi.org/10.1016/j. matdes.2010.01.038

4. López DA, Pérez T and Simison SN. The Influence of Microstructure and Chemical Composition of Carbon and Low Alloy Steel in $\mathrm{CO}_{2}$ Corrosion. A State-of-the-Art Appraisal. Materials \& Design. 2003; 24:561-575. http://dx.doi. org/10.1016/S0261-3069(03)00158-4

5. Li T, Yang Y, Gao K and Lu M. Mechanism of Protective Film Formation During $\mathrm{CO}_{2}$ Corrosion of X65 Pipeline Steel. Journal of University of Science and Technology Beijing, Mineral, Metallurgy, Material. 2008; 15(6):702-706. http:// dx.doi.org/10.1016/S1005-8850(08)60274-1

6. Alawadhi K and Robinson MJ. Preferential Weld Corrosion of X65 Pipeline Steel in Flowing Brines Containing Carbon Dioxide. Corrosion Engineering, Science and Technology. 2011; 46(4):318-329. http://dx.doi.org/10.1179/ 147842210X12695149033891

7. Muñoz J, Genesca R, Duran J and Mendoza A. Mechanism of $\mathrm{FeCO}_{3}$ Formation on API X70 Pipeline Steel in Brine Solutions Containing $\mathrm{CO}_{2}$. In: Proceedings of the Corrosion; 2005; Houston. NACE International; 2005. Paper n. 05297.

8. Mohammadi F, Eliyan FF and Alfantazi A. Corrosion of Simulated Weld HAZ of API X-80 Pipeline Steel. Corrosion Science. 2012; 63:323-333. http://dx.doi.org/10.1016/j. corsci.2012.06.014

9. Villareal J. Corrosion in Multiphase Systems with Slug Flow, Case: Crude oil, $\mathrm{CO}_{2}$, Sea Water on the Carbon Steel 1018. [Thesis]. Bucaramanga: Santander Industrial University; 2003. In Spanish

10. Hosni ME. Influence of Temperature and Thiosulphate on the Corrosion Behavior of Steel in Chloride Solutions Saturated in CO. Materials \& Design. 2009; 30:3420-3427. http://dx.doi. org/10.1016/j.matdes.2009.03.028

11. Tan YJ, Bailey S and Kinsella B. Mapping Non-Uniform Corrosion Using the Wire Beam Electrode Method. I. Multi-phase Carbon Dioxide Corrosion. Corrosion Science. 2001; 43:1905-1918. http://dx.doi.org/10.1016/ S0010-938X(00)00190-6

12. Lopez WH and De Sanchez S. The Influence of Carbon Steel Microstructure on Corrosion Layers. An XPS and SEM Characterization. Applied Surface Science. 2003; 207:69-85. http://dx.doi.org/10.1016/S0169-4332(02)01218-7

13. De Waard C and Milliams DE. Prediction of Carbonic Acid Corrosion in Natural Gas Pipelines. In: Proceedings of the First International Conferences "Internal and External Protection of Pipes”; 1975. University of Durham; 1975.

14. Schmitt G and Rothmann B. Studies on the Corrosion Mechanism of Unalloyed Steel in Oxygen - Free Carbon Dioxide Solutions: Part 1. Kinetics of the Liberation of Hydrogen. Part 1l. Kinetics of Iron Dissolution $\mathrm{CO}_{2}$ Corrosion in
Oil and Gas Production. In: Proceedings of the Corrosion; 1984; Houston. Houston: NACE International; 1984. p. 163-176

15. George KS and Nešić S. Investigation of Carbon Dioxide Corrosion of Mild Steel in the Presence of Acetic Acid-Part 1: Basic Mechanisms. Corrosion. 2007; 63(1):178-186. http:// dx.doi.org/10.5006/1.3278342

16. Nešić S and Nordesveen M. A Mechanistic Model for Carbon Dioxide Corrosion of Mild Steel in the Presence of Protective Iron Carbonate Films-Part 2: A Numerical Experiment. Corrosion. 2003; 59:497-506.

17. Schmitt G, Gudde T and Strobel-effertz E. Fracture Mechanic Properties of $\mathrm{CO}_{2}$ Corrosion Product Scales and Their Relation to Localized Corrosion. In: Proceedings of the Corrosion; 1996; Denver. Houston: NACE International; 1996. Paper n. 9.

18. Wainer E, Brandi S and Mello F. Soldagem Processos e Metalurgia. Editorial Edgard Blucher Ltda; 2000.

19. American Society for Testing and Materials - ASTM. ASTM G1 - 03(2011): Standard Practice for Preparing, Cleaning, and Evaluating Corrosion Test Specimens. Annual Book of ASTM Standard, Current Edition Approved; 2011. http:// dx.doi.org/10.1520/G0001-03R11

20. Mishra B, Al-Hassan S, Olson DL and Salama MM. Development of a Predictive Model for Activation-Controlled Corrosion of Steel in Solutions Containing Carbon Dioxide. Corrosion. 1997; 53(11):852-859. http://dx.doi. org/10.5006/1.3290270

21. Srinivasan $\mathrm{S}$ and Kane RD. Prediction of Corrosivity of $\mathrm{CO}_{2} / \mathrm{H}_{2} \mathrm{~S}$ Production Environments. Paper 011. Corrosion NACE. 1996.

22. Nesic S, Solvi GT and Enerhaug J. Comparison of Rotating Cylinder and Pipe Flow Tests for Flow- Sensitive Carbon Dioxide Corrosion. In: Proceedings of the Corrosion; 1996; Denver. Houston: NACE International, 1996. p. 777-787.

23. Crolet JL, Thevenot $\mathrm{N}$ and Nešic S. The Role of Conductive Corrosion Products in the Protectiveness of Corrosion Layers. Corrosion. 1998; 54(3):194-203. http://dx.doi. org/10.5006/1.3284844

24. Dugtand H and Hemmer M. Effect of Steel Microstructure on Corrosion Rate and Protective Iron Carbonate Film Formation. Corrosion. 2001; 57(4):369-378. http://dx.doi. org/10.5006/1.3290361

25. Al-Hassan S, Mishra B, Olson DL and Salama MM. Effect of Microstructure on Corrosion Steels in Aqueous Solution Containing Carbon Dioxide. Corrosion. 1998; 54(6):480-492. http://dx.doi.org/10.5006/1.3284876

26. Masakatsu $\mathrm{H}$ and Takake H. Effect of Environmental Factor and Microstructure on Morphology of Corrosion Products in $\mathrm{CO}_{2}$ Environments. In: Proceedings of the Corrosion; 1999; San Antonio. Houston: NACE International; 1999. Paper 13.

27. Linter BR and Burstein GT. Reactions of Pipelines Steels in Carbon Dioxide Solutions. Corrosion Science. 1999; 41:117-139. http://dx.doi.org/10.1016/S0010-938X(98)00104-8

28. Heuer JK, Stubbins JF. Microstructure Analysis of Coupons Exposed to Carbon Dioxide Corrosion in Multiphase Flow. Corrosion. 1998; 54(7):566-575. http://dx.doi. org/10.5006/1.3284885

29. Dugstad A. The importance of $\mathrm{FeCO}_{3}$ Super Saturation of Carbon Steel. In: Proceedings of the Corrosion; 1992; Houston. Houston: NACE International; 1992. Paper n.14.

30. Hebb TL, Kruger JE and Mackenzie RC. Differential Thermal Analysis: Fundamental Aspects vol. 1. New York: Academic Press; 1970.327 p.

31. Kissinger HE, McMurdie HF and Simpson BSJ. Thermal Decomposition of Manganous and Ferrous Carbonates. Journal of the American Ceramic Society, 1956; 39(5):168-172. 
32. Song FM, Kirk DW, Graydon JW and Cormack DE. Prediction for $\mathrm{CO}_{2}$ Corrosion of Active Steel Under a Precipitate. Corrosion. 2004; 60(9):845-851. http://dx.doi. org/10.5006/1.3287866

33. Kinsella B, Tan YJ and Bailey S. Electrochemical Impedance Spectroscopy and Surface Characterization Techniques to Study Carbon Dioxide Corrosion Product Scales. Corrosion. 1997; 54(10):835-842. http://dx.doi. org/10.5006/1.3284803
34. Rajappa S, Zhang R and Gopal M. Modeling the diffusion Effects Through the Iron Carbonate Layer in the Carbon Dioxide Corrosion of Carbon Steel. In: Proceedings of the Corrosion; 1998; Houston. Houston; NACE International; 1998. Paper n. 26.

35. Wu SL, Cui ZD and Yang XJ. Characterization of the Surface Film Formed from Carbon Dioxide Corrosion N80 Steel. Materials Letters. 2004; 58:1076-1081. http://dx.doi. org/10.1016/j.matlet.2003.08.020 